\title{
State of Maintenance in Relation to Property Regime, Tenancy and Uses of a Large Sample of Residential Buildings Located in the Most Vulnerable Areas of the City of Barcelona
}

\author{
Sara Vima-Grau ${ }^{1}$, Còssima Cornadó $^{2}$ and Pilar Garcia-Almirall ${ }^{3}$ \\ ${ }^{1} \mathrm{PhD}$ researcher and Teaching Assistant of the Department of Technology in Architecture, FPU Grant \\ by MECD, Universitat Politècnica de Catalunya, ETSAB, Barcelona, sara.vima@upc.edu \\ ${ }^{2}$ Lecturer professor Serra Húnter Fellow, PhD architect of the Department of Technology in \\ Architecture, Universitat Politècnica de Catalunya, ETSAB, Barcelona, cossima.cornado@upc.edu \\ ${ }^{3}$ Professor of the Department of Technology in Architecture, Universitat Politècnica de Catalunya- \\ BarcelonaTECH, ETSAB, Barcelona, pilar.garcia-almirall@upc.edu
}

\begin{abstract}
In a context of downturn of public investment after the financial crisis of 2007, an increase of social and economic inequality takes place in territories and cities. Socio-residential vulnerability is intensified in certain urban areas where processes of socioeconomic and socio-spatial regression are related with the resident population difficulties to access resources for the intervention and maintenance of an aging residential building stock that gradually decays. Mediterranean cities in Southern Europe and precisely the city of Barcelona face the added difficulty of counting with a residential built stock of mostly private property, accounting many situations of horizontal property in which each building is managed by a community of owners who are not necessary householders and users. The present study consists of an analysis of the relation between the state of maintenance of residential buildings and the property regime, tenancy and uses, based on the observation of common spaces and elements of a large sample of buildings located in the most vulnerable areas of the city of Barcelona. The provided results can contribute to foster improvements in future public rehabilitation programs and policies. Particularly according to local challenges to guarantee and promote durability of a mostly privatelyowned residential built stock that is located in areas where socioeconomic difficulties hinder the residents' capacity to carry out rehabilitation or maintenance actions. Management of the maintenance of the residential built stock must take into account the repercussion of particularities in property regimes, tenancy and uses, especially when it refers to common spaces and elements of residential buildings.
\end{abstract}

Keywords: State of Maintenance, Property Regime, Form of Tenure, Building Pathology, Vulnerable Housing Stock.

\section{Introduction}

In the current context of regression of public and private investment in the construction sector, the obsolescence of the existing residential building stock in areas of the city that are particularly vulnerable is a matter of high concern in the city of Barcelona (Ajuntament de Barcelona, 2016). A city where the design and provision of public policies to support maintenance and rehabilitation faces the challenge to address the predominance of a privatelyowned residential building stock mostly characterized by a horizontal structure of ownership. This fact places the inhabitants, both users and owners, in a central role for the implementation of maintenance and rehabilitation actions of an aging housing stock (Cerezo, 2018). 
In this context, current debates regarding the lack of maintenance and obsolescence of the existing urban fabric consider not only the decay of the built environment at different scales but also the increasing risk of social and residential exclusion affecting its inhabitants. The distinction between physical factors, related to the building stock material and technical processes, and behavioural factors, related to human actions, possibilities and struggles, is at the same time explanatory of the causes and descriptive of the effects of the progressive deprivation of the urban existing tissue. (Thomsen et al. 2015 and 2017).

The present paper provides a cross-analysis of quantitative and qualitative indicators of the state of maintenance of a large sample of residential buildings located in five of the most vulnerable neighbourhoods of the city of Barcelona, in relation to the property regime, tenancy and risk of residential exclusion as well as occupancy and uses within the building. This contribution can provide tools to consider the impact of this socioeconomic aspects on the issue of obsolescence and it aligns with the aim of the Council of Barcelona to foster the design of specific integral public rehabilitation programs that can support the most vulnerable tenants and householders to access maintenance and improvement actions at present and in long term. (Diari Oficial de la Generalitat, 2018).

\section{Objectives}

The main objectives of this research are:

To describe the building stock in different vulnerable neighbourhoods according to the

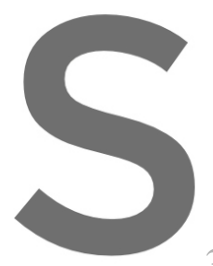
type of observed damages and the state
To analyse and detect the impact of
tenancy and risk of residential xxclusion
state of maintenance and conser ation
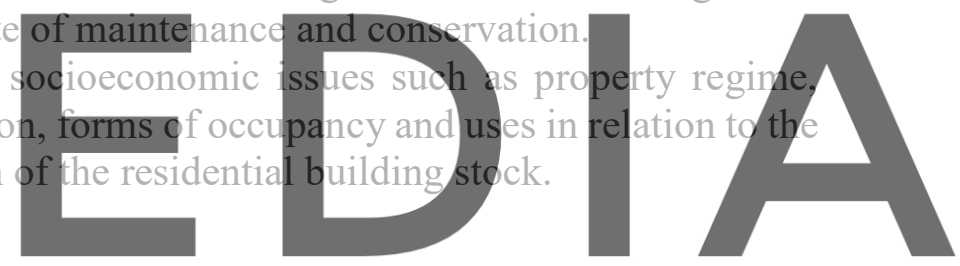

3 Methodology

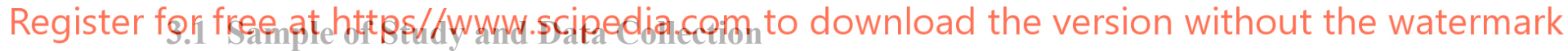

The main sources for this paper are, firstly, a study on the detection of the most vulnerable areas of the city of Barcelona (Garcia-Almriall et al., 2017), and the following study on the prediagnosis of the state of conservation of the building stock in 16 vulnerable neighbourhoods (Cornadó et al., 2017).

This paper presents a cross-analysis of data of a total sample of 2434 buildings located in five of the previously studied vulnerable neighbourhoods that are selected for their very diverse characteristics. El Raval (1119/1685 analysed buildings) and La Barceloneta (737/1074 buildings) are central neighbourhoods with a historic urban tissue with mainly constructions of the XIX century. Ciutat Meridiana (54/78 buildings) and El Besòs (188/281 buildings) are peripheric neighbourhoods in the north and south of river Besòs and consist of a modern urban tissue with mainly open block and tower constructions built between 1950 and 1975. Trinitat Vella (345/592 buildings) is also a peripheric neighbourhood built in the same period, but its urban tissue consists of attached constructions between party walls conforming a closed urban block (Figure 1). 

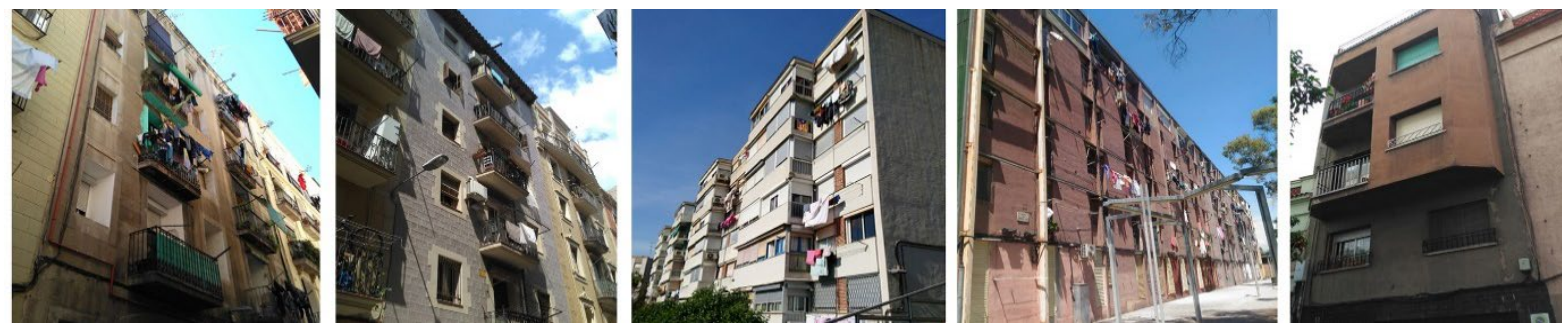

Figure 1. Different type of buildings of the five analysed neighbourhoods. From left to right: El Raval, La Barceloneta, Ciutat Meridiana, El Besòs and Trinitat Vella.

\subsection{Data Analysis}

\subsubsection{Building pathology: type of observed damages}

Firstly, this paper provides an analysis of a series of observed damages according to their relevance on the studied areas. The available data was obtained during a fieldwork campaign (Cornadó et al., 2017) (Figure 2). The described damages are: cracks in bearing walls, façade buckling, risk of material detachment in facades and roofs, dampness (rising damp, moisture and rainwater leaks), degraded windows and woodwork, rusty metal elements, cracks in the facing, stains and dirt.
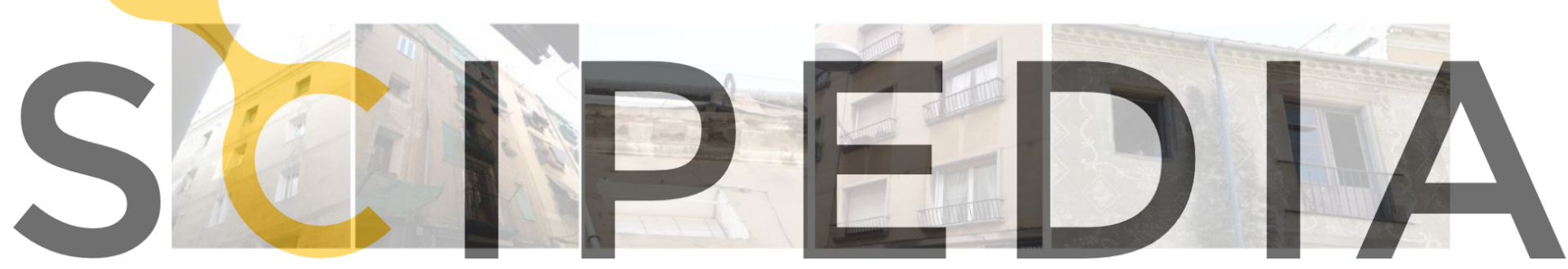

Figure 2. Fieldwork images of observed damages.

Register for free at https//www.scipedia.com to download the version without the watermark 3.2.2 State of maintenance and conservation in relation to property, tenancy and uses

Secondly, this paper presents qualitative and quantitative indicators to statistically analyse the state of maintenance and conservation of the building stock: a qualitative indicator that describes the need of rehabilitation of the building stock obtained in a campaign of fieldwork (Cornadó et al., 2017) (Figure 3), a quantitative indicator of the superposition of the previously described damages within one single building (Cornadó et al., 2017), and finally a quantitative indicator of the existence of administrative requirements and orders of conservation provided by the Council of Barcelona (Garcia-Almirall et al., 2017).
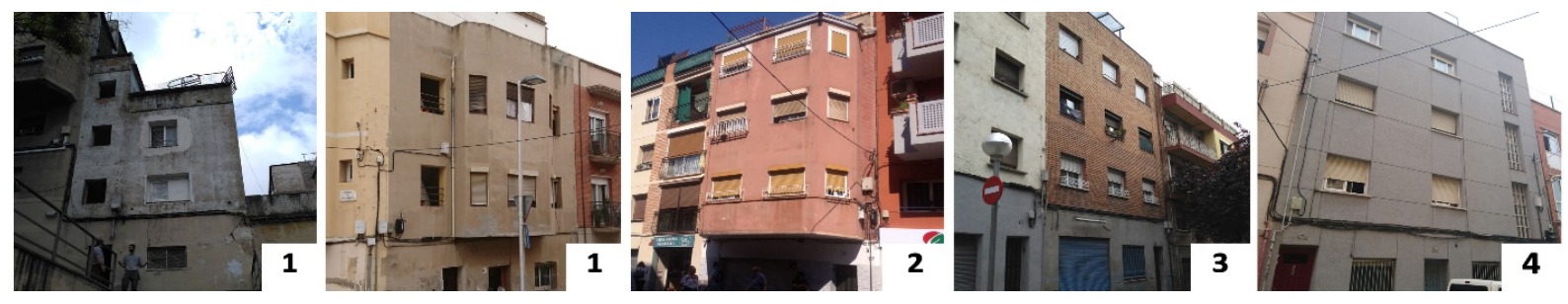

Figure 3. Fieldwork images of buildings with different results the need of rehabilitation indicator. 
Results from the three indicators are classified according to four levels in relation to the state of maintenance and conservation of the building stock (Table 1), and they are further analysed according to socioeconomic variables related with property, tenancy and uses (Table 2):

Table 1. Qualitative and quantitative indicators of the state of maintenance and conservation.

\begin{tabular}{ccccc}
\hline \multicolumn{1}{c}{ Indicators } & Level 1 & Level 2 & Level 3 & Level 4 \\
\hline - Need of rehabilitation & High & Regular & Low & Very low \\
\hline - Superposition of damages & $7-9$ & $4-6$ & $1-3$ & 0 \\
\hline - Administrative requirements & More than 2 & 2 & 1 (interior) & 1 (façade) \\
\hline Sate of maintenance & Very low & Low & Regular & Adequate \\
\hline
\end{tabular}

Table 2. Socioecnomic variables, data and sources.

\begin{tabular}{|c|c|c|}
\hline Variables & Data & Source \\
\hline - Property regime & Horizontal Property & Garcia-Almirall, 2017 \\
\hline & $\begin{array}{l}\text { Vertical Property: } \\
\text { legal entity or natural person }\end{array}$ & Statistical Database \\
\hline $\begin{array}{l}\text { - Risk of residential } \\
\text { exclusion }\end{array}$ & $\begin{array}{l}\text { - Application for public rental aid } \\
\text { Number of evictions }\end{array}$ & $\begin{array}{c}\text { Garcia-Almirall, } 2017 \\
\text { Statistical Database }\end{array}$ \\
\hline $\begin{array}{l}\text { - Tenancy and uses of } \\
\text { the building }\end{array}$ & $\begin{array}{l}\text { Blocked and empty premises } \\
\text { Empty premises in ground floors }\end{array}$ & $\begin{array}{c}\text { Cornadó et al., } 2017 \\
\text { Fieldwork }\end{array}$ \\
\hline
\end{tabular}

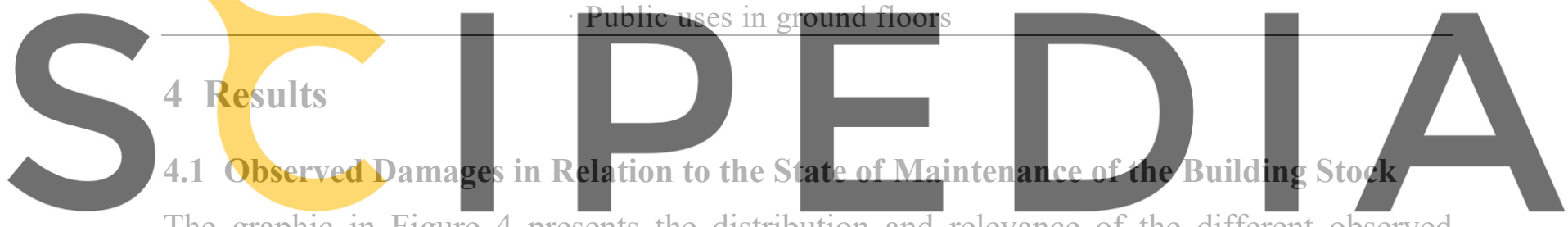

The graphic in Figure 4 presents the distribution and relevance of the different observed Register for free at https//wWw.scipedia.com to download the version without the watermark Observed damages: $\quad$ R El Raval Sud

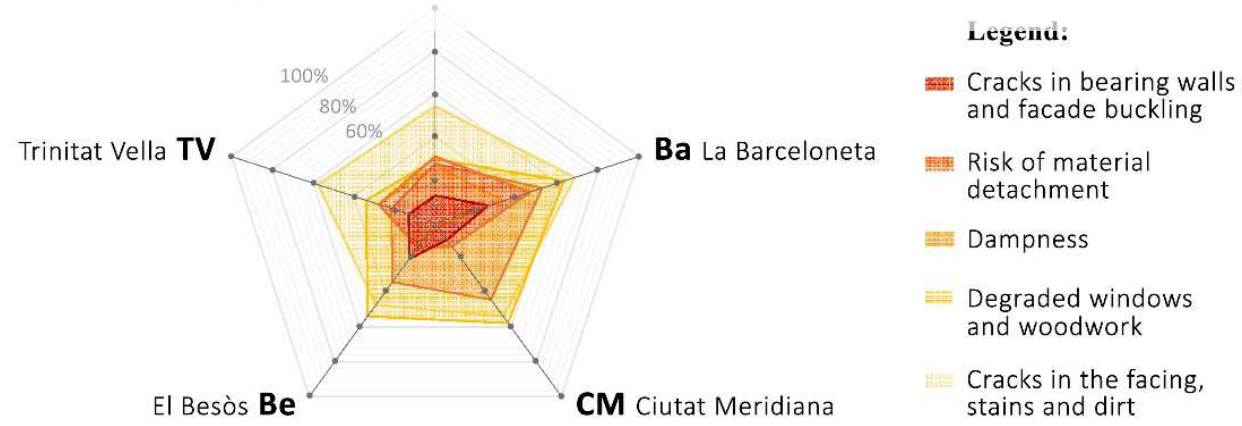

Figure 4. Proportion and distribution of observed damages.

The most abundant observed damages are those that are strictly related with a lack of ordinary and extraordinary maintenance actions: cracks in the facing, stains and dirt, as well as damages in windows and woodwork and carpentries. Their proportion according to neighbourhood varies between 55-68\%. The proportion of cases with dampness is still quite relevant and a little bit more variable among neighbourhoods: between 50\% in La Barceloneta 
and Ciutat Meridiana, 30\% in El Besòs and El Raval, and 20\% in Trinitat Vella. There is a considerable number of cases with risk of material detachment, particularly in La Barceloneta (near the 50\%), and still importantly in El Raval and Trinitat Vella (around the 30\%), while it is very low in El Besòs and Ciutat Meridiana (15\%). Finally, the proportion of cases presenting damages of mechanic structural origin such as cracks in the bearing walls is a lot lower and it presents high variability from La Barceloneta and el Besòs, the locations with a highest percentage $(25 \%)$, to Ciutat Meridiana $(10 \%)$. The graphic in Figure 5 presents the distribution of three groups of indicators that are classified in four levels in order to assess the state of maintenance of the whole sample:
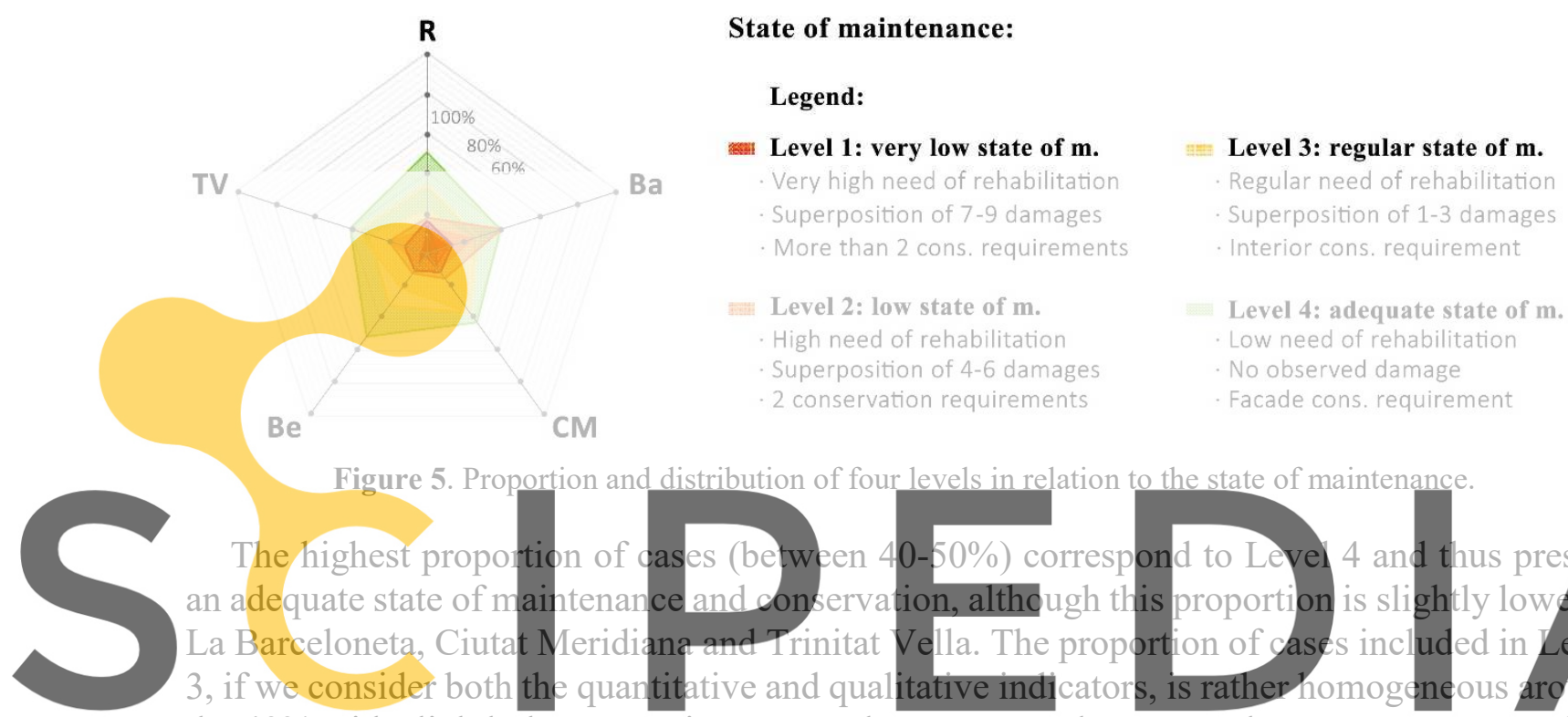

Figure 5. Proporti

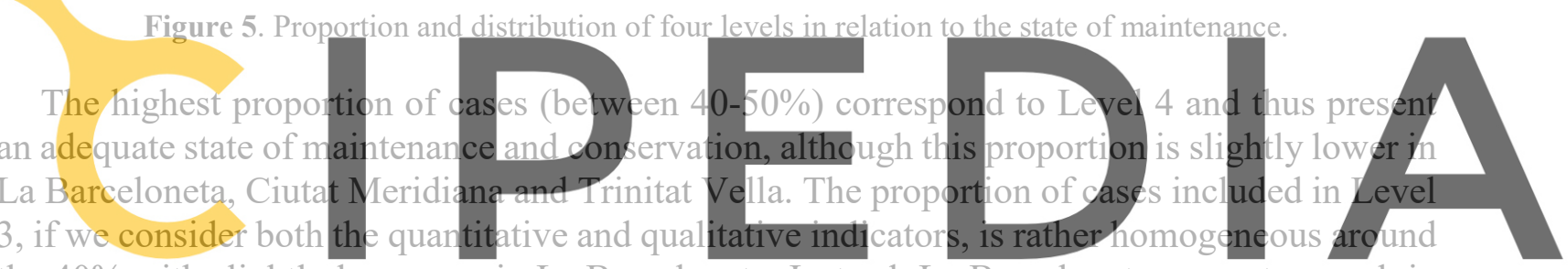

2 conservation requirements

Facade cons, requirement

the $40 \%$ with slightly less cases in La Barceloneta. Instead, La Barceloneta presents a peak in

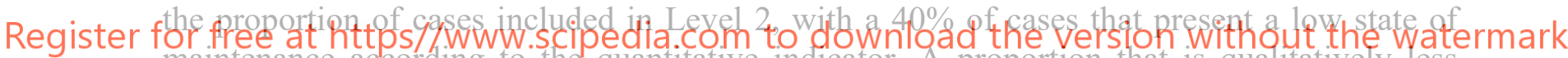
maintenance according to the quantitative indicator. A proportion that is qualitatively less important but still accentuated: $25 \%$ of cases in Level 2 in La Barceloneta in comparison to a $18 \%$ in Trinitat Vella and between $7-13 \%$ in the rest of areas. Finally, the qualitative indicator provides an almost homogeneous distribution of cases included in Level 1 between $10 \%$ in El Besòs to $16 \%$ in El Raval, including cases with a very poor state of conservation. Even though the proportions of administrative requirements are very low (mostly under $10 \%$ ), there is a $16 \%$ of cases with administrative requirements for interior conservation in El Raval.

\subsection{Building Pathology and State of Maintenance in Relation to the Property Regimes}

The cross-analysis of the distribution of damages and the indicators of the state of maintenance according to different property regimes is presented in Figure 6. The proportion of observed damages within cases of horizontal property is slightly higher if compared to the results of the full sample in Figure 4, and clearly higher if compared to the results for cases with a vertical property regime. Besides, there is a clear decrease of the proportion of cases presenting damages of mechanic structural origin as well as risk of material detachment for vertical properties. More particularly, vertical juridical properties clearly present lower percentages of all types of damages in comparison to vertical physical properties. 


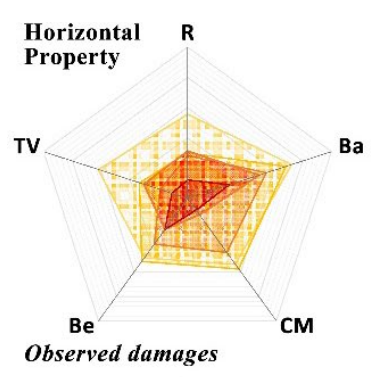

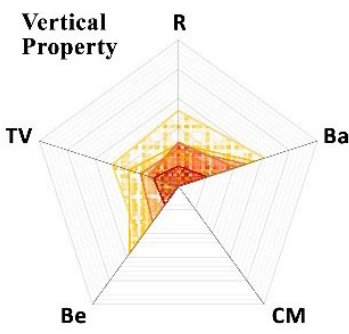

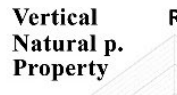

Ba
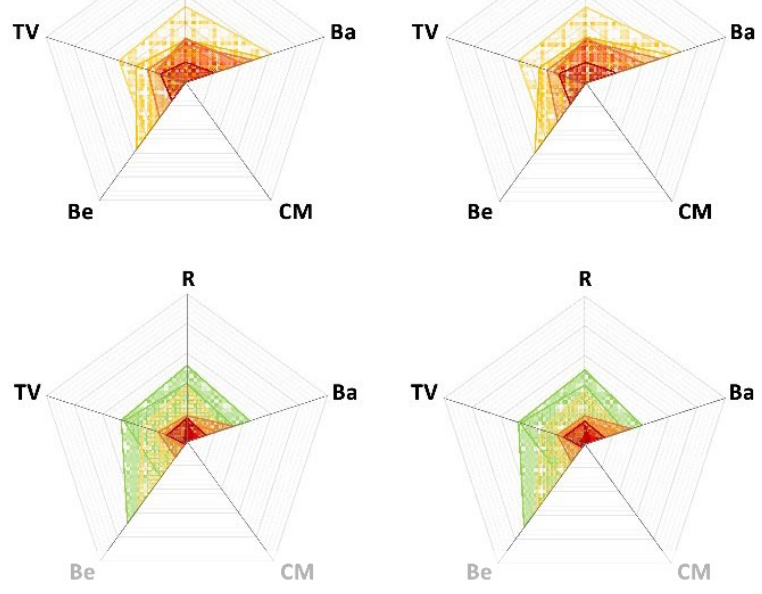

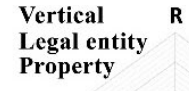

Ba

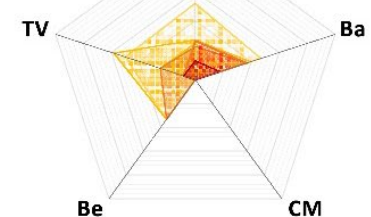

$\mathrm{Be}$

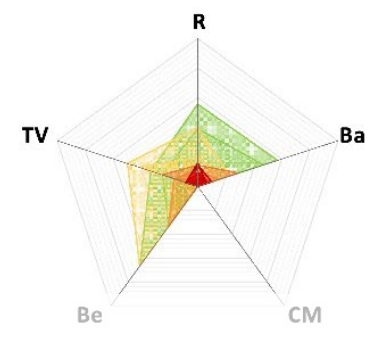

State of maintenance

Figure 6. Proportion of observed damages and the state of maintenance in relation to property regimes.

Regarding quantitative and qualitative indicators of the state of maintenance and conservation of the building stock, similar results can be observed. The proportion of cases presenting an adequate state (Level 4) is clearly inferior for horizontal properties. Vertical properties include a much higher percentage ofbuildings in an adequate state, particularly in El

Besòs, and most spedifica

Instead, vertical propertion

number of cases with

conservation, the proportion of cases is more

neighbourhoods and it is particularly lower

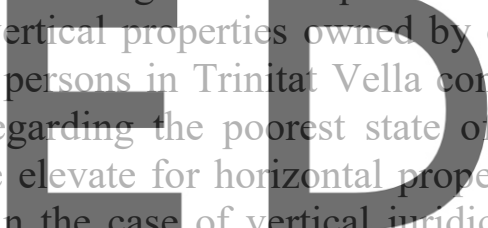

of $\mathrm{La}$ B

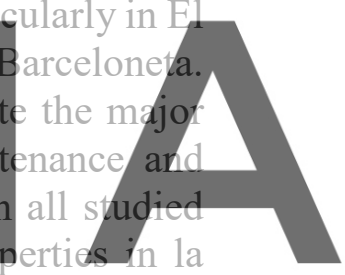

Barceloneta and El Besòs.

Register for free at https//www.scipedia.com to download the version without the watermark 4.3 Building Pathology and State of Maintenance in Relation to Tenancy and Risk of

\section{Residential Exclusion}

In comparison to the results presented in Figures 4 and 5, Figure 7 clearly shows how the proportion of observed damages and the proportion of cases with a lower state of maintenance is much higher for those buildings in which the resident community has faced eviction processes in the last years. Results according to buildings in which many residents apply for rental social aid are very similar. This observation is particularly clear in La Barceloneta, El Besòs and Trinitat Vella, while it is also significant in El Raval and Ciutat Meridiana.

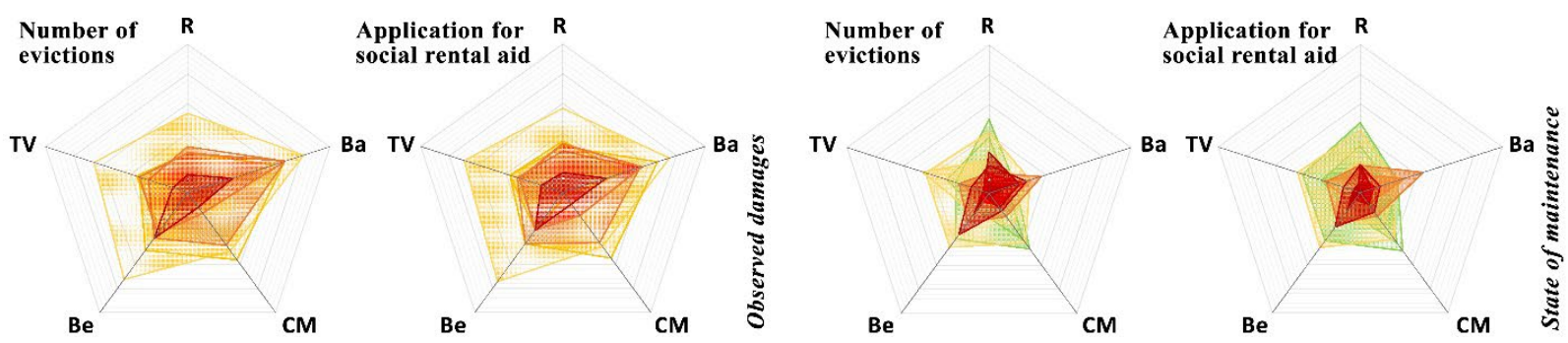

Figure 7. Proportion of observed damages and state of conservation according to risk of residential exclusion. 


\subsection{Building Pathology and State of Maintenance According to Occupancy and Uses of Residential and Ground Floors}

The results presented in Figure 8 highlight the very high impact of the existence of blocked unused spaces both in residential and ground floors in relation to the observation of damages and the very poor state of conservation for all coincident cases. Remarkably, empty premises in ground floors present a similar correlation, particularly in Ciutat Meridiana and El Besòs.

Additionally, it is interesting to consider the impact of a different use of ground floors, be it of private access (housing, garage or storage) or of public access (commercial and services). In the case of El Raval, the percentage of cases with a very low state of maintenance is higher in buildings with housing or storage uses on the ground floor. Nevertheless, both the proportion of observed damages and of buildings with a very low state of maintenance tend to increase in buildings with commercial and services in the ground floor, with exceptions in El Besòs where the proportion of some types of damages decreases significantly while there is a higher proportion of buildings in an adequate state.
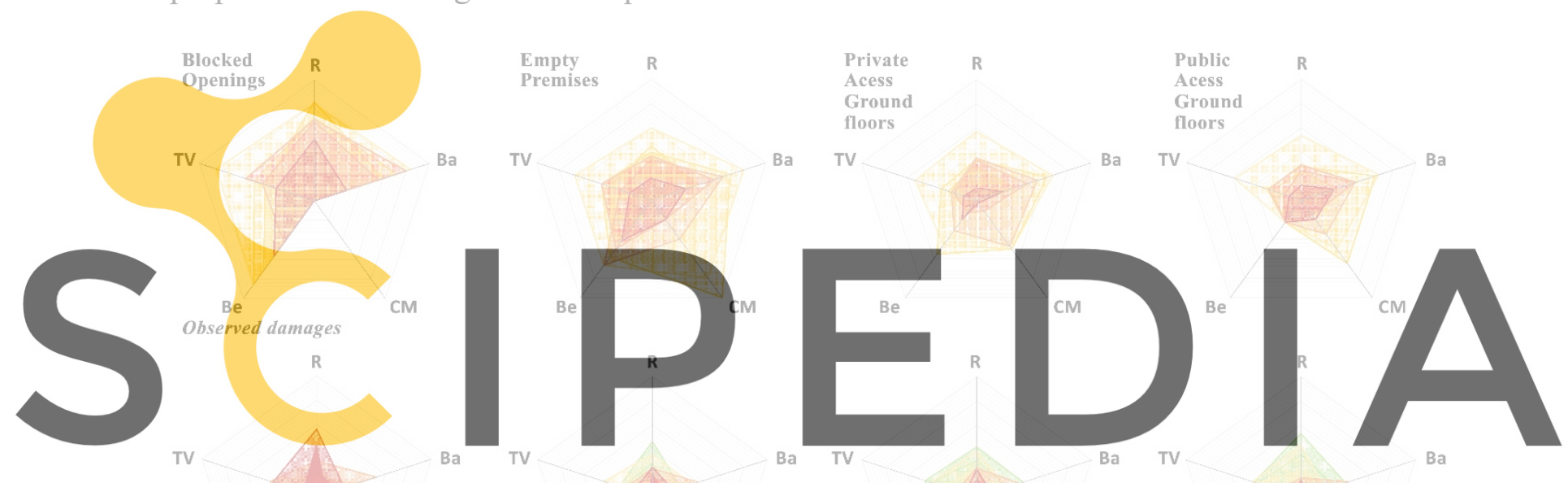

Register for free at https//www.scipedia.com to download the version without the watermark

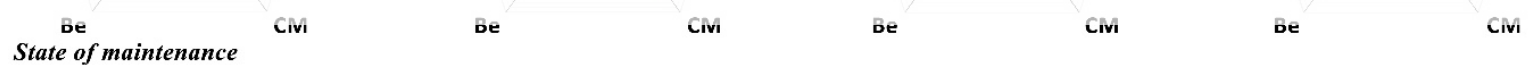

Figure 8. Proportion and distribution of observed damages and four levels of the state of conservation according to the occupancy and uses of residential and ground floors.

\section{Conclusions}

First of all, there is a clear relation between the abundance of most observed damages in common elements and spaces of buildings and lack of ordinary or extraordinary maintenance actions. Results regarding the qualitative indicators of the state of maintenance and conservation also confirm the existence of a low percentage of buildings that need an urgent intervention of rehabilitation, while they highlight a considerable proportion of cases in which the state of maintenance is not yet adequate.

In this context, the higher proportion of observed damages and lower state of maintenance of privately-owned buildings with a horizontal structure of property confirms the consequences of what can be pointed as an added difficulty hindering the implementation of maintenance 
actions. The particularly lower proportions of damages and the increase of the adequate states of maintenance for the specific case of vertical juridical property in La Barceloneta and El Raval can be explained by the speculative pressure in the historic central areas, where the acquisition and renovation of entire buildings is frequent.

Secondly, the clear impact of socioeconomic variables that are closely related to the risk of residential exclusion in communities, confirms how socioeconomic difficulties and residential instability are also explanatory factors of the gradual decay of the residential building stock.

Finally, the high correlation between the existence of empty premises both in residential and ground floors and the accumulation of severe damages and a poor state of maintenance explains the high impact of a usually prolonged lack of activity. Besides, in most studied neighbourhoods where the common ground floor activity is housing, buildings with commercial ground floors present a lower state of maintenance. While in the case of El Raval, in which the common ground floor activity is commercial, the presence of other activities of private access such as housing, provides a sign of deprivation. The correlation between ground floor uses and state of maintenance must be interpreted according to the location and urban activities of each site.

Results from this paper confirm that the design and management of public programs aiming at improving the state of maintenance and conservation of the residential building stock must adapt and consider seriously socioeconomic aspects related with property, tenancy, occupancy and uses, particularly in contexts where the risks of socioresidential exclusion are high.

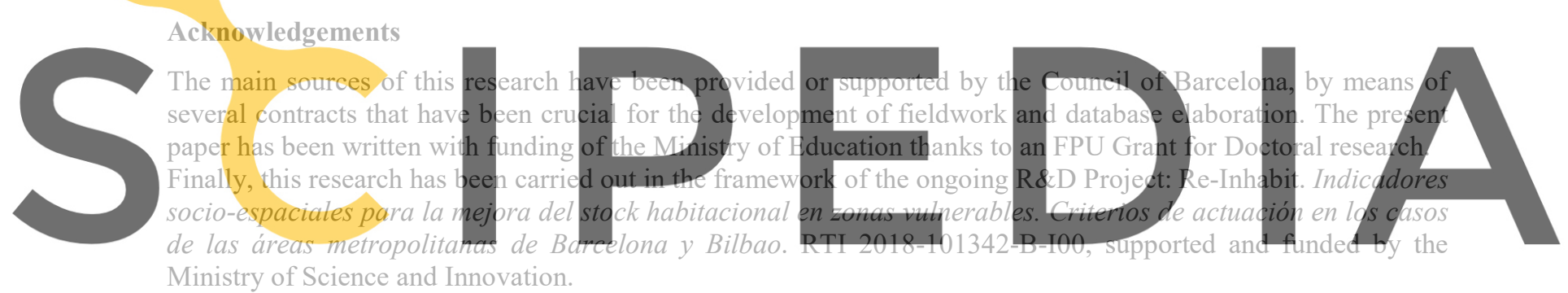

Register for free at https//www.scipedia.com to download the version without the watermark ORCIID

Sara Vima Grau: http://orcid.org/0000-0002-9912-8201

Cossima Cornadó Bardón: http://orcid.org/0000-0003-0553-7176

Pilar Garcia Almirall: http://orcid.org/0000-0002-5918-118X

\section{References}

Ajuntament de Barcelona (2016). Pla pel Dret a l'Habitatge de Barcelona 2016-2025. Resum executiu.

Cornadó, C., Garcia-Almirall, P. and Vima, S. (2017). Prediagnosi de l'edificació residencial en els àmbits de vulnerabilitat de la ciutat de Barcelona. Ajuntament de Barcelona.

CVE-DOGC-A-18157071-201 (2018). Anunci de la Convocatòria del Programa de Finques d'Alta Complexitat. Diari Oficial de la Generalitat de Catalunya (DOGC). Núm 7642-14.6.2018.

Garcia-Almirall, P., Vila, G., Vima, S. and Uzqueda, A. (2017). Estudi i detecció a la ciutat de Barcelona d'àmbits de vulnerabilitat residencial. Ajuntament de Barcelona.

Cerezo, Á. (2018). Evolución del derecho de propiedad en cuanto al deber de conservación en la legislación de suelo y urbanismo desde 1956 a 2018, de la triada clásica a la actuación sobre el medio urbano. ACE: Architecture, City and Environment = Arquitectura, Ciudad y Entorno, 13 (38): 81-100, 2018.

Thomsen, A., Van der Flier, K. and Nieboer, N. (2015). Analyising obsolescence, an elaborated model for residential buildings. Structural Survey 33, 3: 210-227.

Thomsen A., Nieboer, N. and Van der Flier, K. (2017). Obsolescence - understanding the underlying processes. ENHR 2015 Conference Lisbon. 